\title{
PENANAMAN KARAKTER KEMANDIRIAN BELAJAR SISWA MELALUI KEGIATAN EKSTRAKURIKULER PRAMUKA DI SMA NEGERI 1 MEMPAWAH
}

\author{
Winda Wahyu Astuti ${ }^{1}$, Hamid Darmadi ${ }^{2}$, Syarif Firmansyah ${ }^{3}$ \\ 1,2,3 Program Studi PPKN Fakultas Ilmu Pendidikan dan Pengetahuan Sosial IKIP PGRI Pontianak \\ Jl. Ampera Nomor 88 Pontianak-78116, Telepon (0561) 748219 Fax. (0561) 6589855 \\ email: windaastuti@gmail.com
}

\begin{abstract}
Abstrak
Tujuan dari penelitian ini secara umum adalah untuk mendapatkan informasi secara objektif mengenai penanaman karakter kemandirian belajar siswa melalui kegiatan Ekstrakurikuler Pramuka di Sekolah Menengah Pertama Negeri 1 mempawah Hilir. Adapun secara khusus tujuan dalam penelitian ini adalah untuk mengetahui. Metode yang digunakan dalam penelitian ini adalah metode penelitian deskriptif. Bentuk penelitian yang digunakan dalam penelitian ini adalah kualitatif. Teknik pengumpul data yang digunakan yaitu observasi partisipatif, teknik komunikasi langsung, studi dokumenter, gabungan/triangulasi, dan, serta studi kepustakaan. Adapun alat pengumpul data pada penelitian ini panduan observasi, panduan wawancara, dokumen-dokumen, data triangulasi, dan sumber-sumber penelitian terdahulu. Teknik analisis data dalam penelitian menggunakan model Miles dan Huberman yang meliputi reduksi data, disply data, kesimpulan dan verifikasi. Hasil dari penelitian dapat disimpulkan bahwa: (1) Bentuk karakter kemandirian belajar siswa meliputi disiplin, percaya diri, tanggung jawab, berjiwa kepemimpinan dan toleransi antar sesama; (2) Adapun faktor yang mempengaruhi karakter kemandirian belajar siswa melalui kegiatan Ekstrakurikuler Pramuka meliputi kegiatan baris berbaris, upacara, permainan, perkemahan dan perjalanan lintas alam atau pengembaraan; (3) Upaya yang dilakukan Pembina kesiswaan dalam penanaman karakter kemandirian belajar melalui Ekstrakulikuler Pramuka meliputi: (1) penerapan sistem among; (2) mengelola satuan pramuka; (3) menciptakan kegiatan yang menarik, menyenangkan, dan mengandung nilai-nilai pendidikan; (4) memahami siswa dan kebutuhannya.
\end{abstract}

Kata Kunci: Karakter Kemandirian Belajar, Ekstrakulikuler Pramuka.

\begin{abstract}
The purpose of this study in general is to obtain objective information about the character of student learning independence through the Scout Extracurricular activities at Negeri 1 Lower Middle School. The specific purpose of this research is to find out. The method used in this research is descriptive research method. The form of research used in this study is qualitative. Data collection techniques used were participatory observation, direct communication techniques, documentary studies, joint / triangulation, and, as well as literature studies. The data collection tools in this study were observation guides, interview guides, documents, triangulation data, and previous research sources. Data analysis techniques in the study used the Miles and Huberman models which included data reduction, data disply, conclusions and verification. The results of the study can be concluded that: (1) The form of the character of student learning independence includes discipline, confidence, responsibility, leadership and tolerance among people; (2) The factors that influence the character of students' learning independence through Scout Extracurricular activities include marching lines, ceremonies, games, camps and cross-country trips or wandering; (3) Efforts made by the students in developing the character of learning independence through Scout Extracurricular include: (1) the application of the among system; (2) managing a scout unit; (3) creating activities that are interesting, fun, and contain educational values; (4) understanding students and their needs.
\end{abstract}

Keywords: Character of Learning Independence, Scout Extracurricular.

\section{PENDAHULUAN}

Upaya peningkatan kualitas pendidikan dilakukan secara menyeluruh meliputi aspek moral, akhlak, budi pekerti, pengetahuan, keterampilan, seni, olah raga dan perilaku. Pengembangan aspek-aspek tersebut bermuara pada pengembangan, kecakapan hidup yang diwujudkan melalui pencapaian kompetensi peserta didik untuk bertahan hidup, menyesuaikan diri, dan berhasil di masa yang akan datang. Pembinaan kesiswaan merupakan bimbingan yang dilakukan secara sadar, terencana, teratur, terarah dan bertanggung jawab untuk mengembangkan 
sikap, kepribadian, pengetahuan dan keterampilan siswa dalam rangka mendukung pencapaian tujuan Pendidikan Nasional. Untuk mencapai salah satu tujuan Bangsa yaitu mencerdaskan kehidupan bangsa, negara menyelenggarakan satu sistem Pendidikan Nasional yang diatur dalam Undang-Undang Nomor 20 tahun 2003 tentang sistem Pendidikan Nasional. Adapun tujuan Pendidikan Nasional yang termuat dalam UU No 20 Tahun 2003 pasal 4 yaitu mencerdaskan kehidupan bangsa dan mengembangkan manusia Indonesia seutuhnya yaitu manusia yang beriman dan bertaqwa kepada Tuhan Yang Maha Esa,berbudi pekerti yang luhur, memiliki pengetahuan dan ketrampilan, sehat jasmani dan rohani, berkepribadian yang mantap dan mandiri serta rasa tanggung jawab kemasyarakatan dan kebangsaan.

Untuk itu, peserta didik harus memiliki kemandirian belajar untuk mengatasi keterbatasan waktu belajarnya. Kemandirian belajar merupakan kemampuan peserta didik dalam mewujudkan kehendak atau keinginannya secara nyata tanpa bergantung pada orang lain. Dalam hal ini, peserta didik mampu belajar sendiri, dapat menentukan belajar yang efektif dan mampu melakukan aktifitas belajar secara mandiri. Selain itu, kemandirian belajar juga akan membentuk sikap peserta didik yang mengarah pada kesadaran belajar sendiri atau belajar mandiri tanpa banyak pengaruh dari orang lain. Hal tersebut sejalan dengan pendapat Yamin (2011: 107) bahwa "belajar mandiri adalah belajar yang dilakukan peserta didik secara bebas menentukan tujuan belajarnya, arah belajarnya, merencanakan proses belajarnya, strategi belajarnya, menggunakan sumber-sumber belajar yang dipilihnya, dan melakukan kegiatan-kegiatan untuk tercapainya tujuan belajarnya". Sardiman (2008) menyebutkan bahwa ciri-ciri kemandirian belajar meliputi:

1. Adanya kecenderungan untuk berpendapat, berperilaku dan bertindak atas kehendaknya sendiri Memiliki keinginan yang kuat untuk mencapai tujuan

2. Membuat perencanaan dan berusaha dengan ulet dan tekun untuk mewujudkan harapan

3. Mampu untuk berfikir dan bertindak secara kreatif, penuh inisiatif dan tidak sekedar meniru

4. Memiliki kecenderungan untuk mencapai kemajuan, yaitu untuk meningkatkan prestasi belajar

5. Mampu menemukan sendiri tentang sesuatu yang harus dilakukan tanpa mengharapkan bimbingan dan tanpa pengarahan orang lain.

Keadaan tersebut mendorong lembaga pendidikan khususnya sekolah, bertanggung jawab untuk memberi pengetahuan, keterampilan dan mengembangkannya melalui pendidikan formal. Kegiatan yang dapat dikembangkan melalui kegiatan di sekolah adalah ekstrakulikuler. Banyak kegiatan ekstrakulikuler di sekolah pada pelaksanaannya dapat mengembangkan peserta didik, salah satunya adalah kegiatan pramuka. Kegiatan pramuka di sekolah di kelola selayaknya 
sebuah organisasi kepanduan yang berkecimpung dalam dunia pendidikan yang bersifat non formal berusaha membantu pemerintah dan masyarakat dalam membangun bangsa. Menurut $\mathrm{P}$. C Kahono (2010:20) prinsip dasar mendidik pramuka yang tertera dalam Dasa Dharma Pramuka, yaitu:

1. Taqwa terhadap Tuhan Yang Maha Esa

2. Cinta alam dan kasih sayang sesama manusia

3. Patriot yang sopan dan ksatria

4. Rela berkirban dan tabah

5. Patuh dan suka bermusyawarah

6. Rajin, terampil, dan gembira

7. Hemat, cermat dan bersahaja

8. Disiplin, berani, dan setia

9. Bertanggung jawab dan dapat di percaya

10. Suci dalam pikira, perkataan dan perbuatan

Isi dari Dasa Darma pramuka tersebut selaras dengan nilai-nilai Pendidikan Pancasila dan Kewarganegaraan. Seperti Taqwa terhadap Tuhan Yang Mahasa selaras dengan nilai-nilai sila pertama Pancasila yaitu nilai patriot dan kstria, tolong menolong, sopan santun, tabah, hemat, rajin, suka bermusyawarah dan sebagainya dalam Pendidikan Pancasila dan Kewarganegaraan hal tersebut sangat dianjurkan karena itu dapat membentuk karakter yang baik generasi muda (young generation) indonesia. Salah satu karakter yang dikembangkan oleh kegiatan ekstrakulikuler gerakan pramuka ini adalah mandiri. Disamping itu, siswa/peserta didik mempunyai otonomi dalam belajar. Otonomi tersebut terwujud dalam beberapa kebebasan sebagai berikut. (1) Peserta didik mempunyai kesempatan untuk ikut menentukan tujuan pembelajaran yang ingin dicapai sesuai dengan kondisi dan kebutuhan belajarnya. (2) Peserta didik boleh ikut menentukan bahan belajar yang ingin dipelajarinya dan cara mempelajarinya. (3) Peserta didik mempunyai kebebasan untuk belajar sesuai dengan kecepatannya sendiri. (4) Peserta didik dapat ikut menentukan cara evaluasi yang akan digunakan untuk menilai kemajuan belajarnya.

Kemandirian dalam belajar ini perlu diberikan kepada peserta didik supaya mereka mempunyai tanggung jawab dalam mengatur dan mendisiplinkan dirinya dan dalam mengembangkan kemampuan belajar atas kemauan sendiri. Sikap-sikap tersebut perlu dimiliki peserta didik karna hal tesrsebut merupakan ciri kedewasaan orang terpelajar.

Berdasarkan uraian diatas, dapat dimaknai bahwa mandiri merupakan salah satu modal penting bagi anak-anak untuk bertahan hidup kelak saat mereka dewasa. tujuan tersebut antara lain: mengembangkan potensi peserta didik secara optimal dan terpadu (bakat, minat, dan kreativitas), mengaktualisasikan potensi peserta didik dalam pencapaian prestasi unggulan sesuai 
bakat dan minat, dan menyiapkan peserta didik agar menjadi warga masyarakat yang berakhlak mulia, demokratis, menghormati hak-hak asasi manusia dalam rangka mewujudkan masyarakat madani (civil society).

Menurut Gunawan, 2012:1), karakter adalah watak atau ciri khas yang dimiliki oleh seseorang sejak lahir. Secara Etimologi karakter berasal dari bahasa latin "character" yang berarti instrumen, sedangkan bahasa Perancis "charessein" berarti mengukir. Karakter adalah cara berpikir dan berperilaku yang menjadi cirri khas tiap individu untuk hidup dan bekerjasama, baik dalam lingkup keluarga, masyarakat, bangsa dan Negara. Individu yang berkarakter baik adalah individu yang bisa membuat keputusan dan siap mempertanggungjawabkan tiap akibat dari keputusan yang ia buat.

Menurut Gunawan, 2012:31) mengatakan bahwa nilai adalah suatu jenis kepercayaan, yang letaknya berpusat pada sistem kepercayaan seseorang, tentang bagaimana seseorang sepatutnya, atau tidak sepatutnya dalam melakukan sesuatu, atau tentang apa yang berharga dan yang tidak berharga untuk dicapai.

Sedangkan menurut Kemendiknas (2012:32) mengatakan bahwa berdasarkan kajian nilai-nilai agama, norma-norma sosial, peraturan atau hukum, etika akademik, dan prinsipprinsip HAM, telah teridentifikasi 80 butir nilai karakter yang dikelompokkan menjadi lima, yaitu; (1) nilai-nilai perilaku manusia dalam hubungannya dengan Tuhan Yang Maha Esa, (2) nilai-nilai perilaku manusia dalam hubungannya dengan diri sendiri, (3) nilai-nilai perilaku manusia dalam hubungannya dengan sesama manusia, (4) nilai-nilai perilaku manusia dalam hubungannya dengan lingkungan, serta (5) nilai-nilai perilaku manusia dalam hubungannya dengan kebangsaan. Sedangkan Kemendiknas merinci secara ringkas kelima nilai-nilai tersebut yang harus ditanamkan kepada siswa, berikut ini deskripsi ringkasnya sebagaimana dijelaskan dalam tabel berikut ini.

Nilai-nilai pendidikan Karakter berasal dari nilai tentang sesuatu. Suatu karakter melekat dengan nilai dari perilaku seseorang. Karenanya tidak ada perilaku anak yang tidak bebas dari nilai. Dalam kehidupan manusia, begitu banyak nilai yang ada di dunia ini, sejak dahulu sampai sekarang (Kesuma, 2011: 11). Nilai-nilai pendidikan karakter yang dikembangkan Kementerian Pendidikan ada delapan belas karakter. Nilai-nilai tersebut bersumber dari agama, pancasila, budaya, dan tujuan pendidikan nasional. Adapun delapan belas nilai tersebut yaitu: religius, jujur, toleransi, disiplin, kerja keras, kreatif, mandiri, demokratis, rasa ingin tahu, semangat kebangsaan, cinta tanah air, menghargai prestasi, bersahabat/komunikatif, cinta damai, gemar 
membaca, peduli lingkungan, peduli sosial, dan tanggung jawab (Pusat Kurikulum Kementerian Pendidikan Nasional, 2009: 9-10).

Kemandirian belajar diartikan sebagai sifat serta kemampuan yang dimiliki siswa untuk melakukan kegiatan belajar aktif, yang didorong oleh motif untuk menguasai sesuatu kompetensi, dan dibangun dengan bekal pengetahuan atau kompetensi yang telah dimiliki. Kemandirian diartikan sebagai suatu kekuatan internal individu dan diperoleh melalui proses individuasi, yang berupa proses realisasi seseorang dan proses menuju kesempurnaan, Ali dan Asrori (2005:114). Sedangkan Sundayana 2016:34) mendefinisikan kemandirian belajar sebagai suatu proses belajar dimana setiap individu dapat mengambil inisiatif, dengan atau tanpa bantuan orang lain, dalam hal mendiagnosa kebutuhan belajar, merumuskan tujuan belajar, mengidentifikasi sumber-sumber belajar, memilih dan menerapkan strategi belajar yang sesuai bagi dirinya, serta mengevaluasi hasil belajarnya. Lebih lanjut. Rahardja (2000:50) mendefinisikan kemandirian dalam belajar diartikan sebagai aktivatas belajar yang berlansungnya lebih didorong oleh kemauan sendiri, pilihan sendiri, dan tanggup jawab sendiri dari pembelajaran.

Fungsi kegiatan ekstrakulikuler yang dijelaskan oleh Sumarna (2006:10) yaitu kegiatan ekstrakulikuler yang dimaksudkan untuk lebih mengaitkan antara pengetahuan yang diperoleh dalam program kurikulum dengan keadaan dan kebutuhan lingkungan. Berdasarkan uraian tersebut dapat disimpulkan bahwa kegiatan ekstrakulikuler berfungsi sebgai penunjang perkembangan personal siswa perluasan minat, pengembangan potensi, dan pemberian kesempatan untuk pembentukan karakter.

Menurut Misbahul (2014:3) Pramuka merupakan anggota Pramuka yang berusia 7 sampai dengan 25 tahun, dan berkedudukan sebagai peserta ddidik, yaitu sebagai pramuka siaga, Pramuka Penggalangan, Pramuka Pandega. Kelompok anggota yang lain yaitu Pembina Pramuka, Andalan, Pelatih, Pamong SAKA, Staf Kwartir dan Majelis Pembimbing. Pramuka adalah nama organisasi yang merupakan wadah proses pendidikan kepramukaan yang dilaksanakan diindonesia. Berdasarkan pendapat di atas dapat dimaknai bahwa Pramuka adalah sebutan bagi anggota Pramuka yang berusia 7 sampai dengan 25 tahun dengan anggota lainnya yang merupakan wadah proses pendidikan untuk membentuk keppribadaian, yang beriman, bertaqwa, berahlak mulia, berjiwa patriotik, taat hukum, disiplin, menjujung tinggi, nilai-nilai luhur bangsa dan membangun Negara Kesatuan Republik Indonesia, mengamalkan Pancasila serta melestarikan linkungan hidup ketika kelak mereka akan terjun di masyarakat.

\section{METODE}


Metode yang digunakan dalam penelitian ini adalah metode deskriptif. Dalam penelitian kualitatif teknik pengumpul data yang digunakan yaitu observasi partisipatif, teknik komunikasi langsung, studi dokumenter, gabungan/triangulasi, dan, serta studi kepustakaan. Sedangkan alat pengumpul data berupa panduan observasi, panduan wawancara, dokumen-dokumen, data triangulasi, dan sumber-sumber penelitian terdahulu.

Observasi dalam penelitian ini dengan terjun langsung di lapangan dan mengamati bagaimana keadaan karakter mandiri siswa, bagaimana bentuk koordinasi antara organisasi kesiswaan dalam penanama karakter siswa dan upaya apa yang dilakukan osis dalam membina karakter tersebut. Wawancara adalah suatu kegiatan yang dilakukan oleh dua orang yang dilakukan secara langsung. Studi dokumentasi merupakan salah satu sumber data penelitian kualitatif yang sudah lama digunakan, karena sangat bermanfaat. Triangulasi teknik, bearti penulis menggunakan teknik pengumpulan data yang berbeda-beda untuk mendapatkan data dari sumber yang sama. Studi literatur, yaitu alat pengumpul data untuk mengungkapkan berbaga inteori yang relevan dengan permasalahan yang sedang dihadapi atau diteliti sebagai bahan pembahasan hasil penelitian.

\section{HASIL DAN PEMBAHASAN}

Penelitian ini dilakukan pada siswa ekstrakulikuler pramuka di SMP Negeri 1 Mempawah Hilir, Kalimantan Barat tepatnya di jalan Gusti Abdul Hamid. SMP Negeri 1 Mempawah Hilir. Penelitian ini bertujuan untuk mengetahui penanaman karakter kemandirian belajar siswa melalui kegiatan ekstrakulikuler pramuka di Sekolah Menengah Pertama Negeri 1 Mempawah Hilir Kabupaten Mempawah.

Peneliti melakukan penelitian untuk memperoleh data yang diperlukan. Adapun langkahlangkah pengumpulan data dimulai dengan mengumpulkan informasi mengenai bentuk karakter kemandirian belajar siswa, faktor yang mempengaruhi karakter kemandirian belajar siswa serta upaya yang dilakukan Pembina kesiswaan dalam penanaman karakter kemandirian belajar melalui Ekstrakulikuler Pramuka di Sekolah Menengah Pertama Negeri 1 Mempawah Hilir. Kemudian melakukan wawancara dengan beberapa nasarumber diantaranya adalah siswa anggota pramuka dan pembina pramuka di Sekolah Menengah Pertama Negeri 1 Mempawah Hilir Kabupaten Mempawah.

Kegiatan baris-berbaris merupakan kegiatan latihan fisik yang dalam pelaksanaannya perlu didasari sikap disiplin, disiplin disinidi tekankan pada sikap yang harus mematuhi aturan yang berlaku sesuai dengan ketentuan yang berlaku, misalnya ketika sikap siap posisi yang harus dilakukan harus sesuai dengan aba-aba yang diberikan oleh pemimpin barisan. Percaya diri 
merupakan sikap yang dimiliki seseorang yang percaya kepada kemampuan sendiri, dalam konteks pendidikan kepramukaan materi baris-berbaris, percaya diri disini dimaksudkan melatih siswa dalam sikap percaya diri dengan latihan gerakan-gerakan cepat terhadap aba-aba yang diberikan oleh pemimpin barisan, bertindak cepat percaya kepada diri-sendiri dan tidak menunggu teman lain melakukan gerakan. Hal ini memberikan kebiasaan kepada siswa dalam mengaplikasikannya dalam kehidupan sehari-hari.

Pada kegiatan latihan baris-berbaris, harus terdapat seorang pemimpin barisan dan peserta yang dipimpin, hal tersebut merupakan latihan kepada siswa untuk mengemban amanah yang diberikan masing-masing, mengembangkan nilai tanggung jawab sebagai pemimpin, dan latihan bertanggung jawab menjadi pesrta atau anggota barisan untuk dipimpin. Suatu barisan harus terdapat seorang pemimpin pasukan untuk mengkoordinir dan memberikan aba-aba dalam pelaksanaan baris-berbaris tidak hanya sekedar belajar menjadi pemimpin, tetapi juga membiasakan sikap siap untuk disiplin.

Oleh karena itu dalam kegiatan kepramukaan juga terdapat permainan-permainan yang menyenangkan serta mengandung nilai pendidikan agar kegiatan lebih menyenangkan dan tidak membosankan untuk siswa, seorang pembia pramuka harus kreatif dalam memberikan permainan, didalamnya tidak hanya kegiatan yang membuat siswa tertarik dan antusias, tetapi mengandung nilai karakter untuk ditanamkan kepada siswa.

Nilai karakter yang dikembangkan dalam permainan dalam kegiatan pramuka, dapat disesuaikan oleh pembina pramuka sesuai dengan kebutuhan siswa, misalnya dilakukan oleh pembina pramuka SMP Negeri 1 Mempawah Hilir "tanggap bencana". Permainan tersebut pembina memberikan suatu permasalahan dalam permainan tersebut, dan kemudian siswa diberikan tugas melakukan apa saja saat terjadinya bencana alam tersebut, setelah permainan tersebut berakhir maka siswa dan pembina mengulas serta berdiskusi mengambil intisari dari kejadian-kejadian tersebut yang baru saja dialaminya. Nilai-nilai yang dikembangkan dapat diulas bersama dan diselingi dengan memberikan nasehat-nasehat kepada siswa.

Aplikasi pramuka yang berkaitan dari karakter seorang siswa, serta upaya pembinaan pramuka menanamkan nilai-nilai karakter di SMP Negeri 1 Mempawah Hilir meliputi: sistem among, mengelola satuan pramuka, menciptakan kegiatan yang menarik, menyenangkan, dan mengandung nilai-nilai Pendidikan, serta memahami siswa dan kebutuhannya.

Upaya menanamkan nilai-nilai karakter siswa di SMP Negeri 1 Mempawah Hilir meliputi sistem among, salah satu metode yang digunakan dalam sistem among adalah cara pelaksanaan di dalam gerakan pramuka. Sistem among adalah hasil pembinaan Raden Mas Suwardi Suryaningrat atau dikenal sebagai Ki Hajar Dewantara, Bapak pendidikan dan pendiri 
pendidikan taman siswa. Kata among berarti pengasuh atau menjaga. Dan orang yang melakukan disebut pamong sesuai dengan pembinaan Ki Hajar Dewantoro adalah "didepan memberi teladan, di tengah ikut membangun atau melakukan, dan di belakang memberi dorongan atau bantuan ke arah kemamndirian. Mengelola satuan pramuka, gerakan pramuka dalam usahanya adalah membuat kegiatan yang menarik bagi anggota pramuka dibawah bimbingan dan tanggung jawab orang dewasa. Berpijak dari hal tersebut, hal yang perlu diperhatikan dalam mengelola satuan gerakan pramuka, dalam pembahasan ini penulis mengerucutkan pada hasil penulisan yaitu satuan gerakan pramuka. Menciptakan kegiatan yang menarik, menyenangkan, dan mengandung nilai-nilai pendidikan, Sasaran yang ingin dicapai dengan penggunaan metode ini ialah siswa merasakan bagaimana menyusun acara kegiatan, bagaimana melaksanakan suatu kegiatan, proses apa saja yang harus dilakukan bila terjadi hambatan dan upaya apa yang dapat mengatasi serta apa saja yang harus dilakukan bila terjadi hambatan dan upaya apa yang dapat mengatasi serta apa yang mereka rasakan bila mana kegiatan yang dilakukan berhasil dengan baik. Serta memahami siswa dan kebutuhannya, Pembina pramuka harus berusaha menyajikan kegiatan yang dapat menarik peserta didik yang sesuai dengan tuntunan kebutuhan mereka. Untuk memenuhi keprluan ini maka pembina pramuka perlu memahami tugas perkembangan siswa yang dibinanya agar kegiatan yang disajikan dapat mengembangkan aspek-aspek psikologi yang berkembang pada siswa. Berikut adalah proses pembentukan karakter kemandirian belajar siswa yang dilakukan pembina pramuka SMP Negeri 1 Mempawah Hilir meliputi (1) Rekreasi dan mengisi waktu dengan kegiatan yang positif; (2) Organisasi siswa; (3) kurikulum.

Sejalan dengan Peraturan Pemerintah Pendidikan dan Kebudayaan Nomor 18A Tahun 2013 tentang implementasi kurikulum fungsi kegiatan ekstrakulikuler antara lain: (1) Fungsi pengembangan, yakni bahwa kegiatan ekstrakulikuler berfungsi untuk mendukung perkembangan personal peserta didik melalui perluasan minat, pengembangan potensi, dan pemberian kesempatan untuk pembentukan karakter dan pelatihan kepemimpinan; (1) Fingsi sosial, yakni bahwa kegiatan ekstrakulikuler berfungsi untuk mengembangkan kemampuan dan rasa tanggung jawab sosial peserta didik. Kompetensi sosial dikembangkan dengan memberikan kesempatan kepda pesrta didik untuk memperluas pengalamaan sosial, praktek, keterampilan sosial dan internalisasi nilai moral dan nilai sosial; (3) Fungsi rekreatif, yakni bahwa kegiatan ekstrakulikuler dilakukan dalam suasana rileks, menggembirakan, dan menyenanggkan sehingga menunjang proses perkembangan peserta didik; (4) Fungsi persiapan karir, yakni bahwa kegiatan ekstrakulikuler berfungsi untuk menggembangkan persiapan karir peserta iddik melalui perkembangan kapasitas.

Menurut Djahiri, (2012: 31) mengatakan bahwa nilai adalah suatu jenis kepercayaan, yang letaknya berpusat pada sistem kepercayaan seseorang, tentang bagaimana seseorang 
sepatutnya, atau tidak sepatutnya dalam melakukan sesuatu, atau tentang apa yang berharga dan yang tidak berharga untuk dicapai.

\section{SIMPULAN}

Berdasarkan dari hasil penelitian secara umum dapat disimpulkan penanaman karakter kemamndirian belajar siswa melalui kegiatan ekstrakulikuler pramuka di Sekolah Menengah Pertama Negeri 1 Mempawah Hilir Kabupaten Mempawah meliputi bentuk-bentuk penanaman karakter, faktor yang mempengaruhi karakter, dan upaya yang dilakukan dalam menanamkan karakter. Adapaun secara rinci djelaskan sebagai berikut: (1) Bentuk karakter kemandirian belajar siswa di Sekolah Menengah Pertama Negeri 1 Mempawah Hilir sebagaian besar meliputi disiplin, percaya diri, tanggung jawab, berjiwa kepemimpinan dan toleransi antar sesama; (2) Adapun faktor yang mempengaruhi karakter kemandirian belajar siswa melalui kegiatan Ekstrakurikuler Pramuka di Sekolah Menengah Pertama Negeri 1 mempawah Hilir meliputi kegiatan baris berbaris, upacara, permainan, perkemahan dan perjalanan lintas alam atau pengembaraan; (3) Upaya yang dilakukan Pembina kesiswaan dalam penanaman karakter kemandirian belajar melalui Ekstrakulikuler Pramuka di Sekolah Menengah Pertama Negeri 1 Mempawah Hilir meliputi: (1) penerapan sistem among; (2) mengelola satuan pramuka; (3) menciptakan kegiatan yang menarik, menyenangkan, dan mengandung nilai-nilai pendidikan; (4) memahami siswa dan kebutuhannya.

\section{DAFTAR PUSTAKA}

Debi Rahmadi (2017). Penanaman Karakter Sopan Santun Oleh Guru Pkn di SMA Negeri 1 Sukadana Kabupaten Kayong Utara. Jurnal Pendidikan Pancasila dan Kewarganegaraan. Vol 1, No.2.

Haryono, Anung. "Belajar Mandiri: konsep dan penerapannya dalam sistem pendidikan dan pelatihan Terbuka jarak jauh”. Dalam http://blog.uin-malang.ac.id.

Martinis Yamin. 2011. Paradigma baru pembelajaran. Jakarta: Gaung persada press.

Rianto, H. Implementasi Pembelajaran Pendidikan Kewarganegraan Berbasis Karakter Bagi Pengembangan Kemandirian Peserta Didik Di SMA. Sosio Religi: Jurnal Kajian Pendidikan Umum, 14(1).

Rohani, Susan (2017). Penanaman Karakter Peduli Sosial Di Sekolah Menengah Pertama Negeri 1 Tangaran Kabupaten Sambas. Jurnal Pendidikan Pancasila dan Kewarganegaraan. Vol 1, No.2.

Tim Penyusun Kamus pusat Pembinaan dan Pengembangan Bahasa, Kamus Besar Bahasa indonesia, (Jakarta: Dept Pend dan Kebudayaan RI, 2002), hal.584

Toni Nasution (2018). Membangun Kemamdirian Siswa Melalui Pendidikan Karakter. Jurnal Pendidikan IPS. Vol 2, No. 1.

Undang-Undang Dasar Republik Indonesia 1945

Undang-Undang Republik Indonesia No.20 Tahun 2013 Tentang Sistem Pendidikan Nasional.

Permendiknas nomor 19 tahun 2007. 